\title{
Plankton monitoring and analysis in the oceans: capacity building requirements and initiatives in Latin-America*
}

\author{
Monitoreo y análisis de plancton en los océanos: requerimientos e iniciativas \\ de formación de capacidades en América-Latina* \\ Carmen E. Morales ${ }^{1 * *}$ \\ ${ }^{1}$ Centro de Investigaciones Oceanográficas del Pacífico Sur-Oriental (COPAS), Estación de Biología Marina, \\ Departamento de Oceanografía, Universidad de Concepción, Casilla 44 Dichato, Chile \\ camorale@udec.cl
}

\begin{abstract}
Resumen.- Las capacidades tanto científicas como técnicas son aspectos claves para lograr los objetivos de entendimiento de los océanos, conservar sus estados y recursos, y predecir los impactos de los cambios climáticos. Diversos programas internacionales relacionados a estudios de los océanos y su monitoreo, así como aquellos concernientes al cambio climático global, incluyen ‘la formación de capacidades’ como un proceso fundamental necesario en orden a alcanzar esos objetivos. La formación de capacidades (CB) en el contexto de monitoreo e investigación es un término usado para describir las acciones concernientes al desarrollo, promoción y mantención de infraestructura, recursos e interacciones relacionadas a las ciencias oceanográficas y los sistemas y servicios relacionados, a nivel individual, organizacional, inter-organizacional, regional y de sistemas. El propósito de este documento es definir los componentes del CB que son esenciales en el alcance de los objetivos derivados de los programas e iniciativas científicas de gran escala que están involucrados en el monitoreo y análisis de comunidades planctónicas en los océanos. Estos componentes incluyen: a) entrenamiento de estudiantes, técnicos, y científicos, b) disponibilidad de plataformas e instrumentación para el muestreo en series de tiempo y análisis de muestras, y c) acceso a sistemas de información y redes de conexión para el intercambio de datos e información. Se discute aquí cómo estos componentes se podrían incluir o han sido en parte concretados en acciones específicas de CB en la región Latino-Americana.
\end{abstract}

Palabras clave: estudios de plancton, capacidades regionales, iniciativas nacionales e internacionales

\begin{abstract}
Both scientific and technical capacities are key issues for achieving the objectives of understanding the functioning of the oceans, conserving their health and resources, and predicting the impacts of climate change. Many international programmes related to ocean studies and monitoring, as well as those concerning global climate change, include 'capacity building' as a fundamental process in order to achieve these objectives. Capacity building (CB) in the context of ocean monitoring and research describes the actions concerning the development, fostering and support of infrastructure, resources and relationships for ocean science and related systems and services at individual, organizational, inter-organizational, regional and system levels. The purpose of this document is to define the CB components which are essential for the accomplishment of the objectives of large-scale scientific programmes and initiatives dealing with monitoring and analysis of planktonic communities in the oceans. These components include: a) training of students, technicians, and scientists, b) availability of platforms and instrumentation for time-series sampling and sample analyses, and c) access to information systems and networking for the exchange of data and information. How these components could be included in specific CB actions or have been partially accomplished in the Latin-American region are here discussed.
\end{abstract}

Key words: plankton studies, regional capacities, national and international initiatives

\section{Introduction}

The oceans are a resource shared by many life forms whether they live permanently in them or on their borders, use them as a means of survival, obtain benefits from them, or just simply contemplate their changing moods between complete calm and furious storms. Some beings, however, lack access to this precious resource, indiscriminately contaminate its waters, or become its victims. Whatever the case, the oceans are common property and, as such, we need to maintain them in good health and with all their benefits. To achieve this, we need to understand the oceans in detail. The study of the oceans has been an almost permanent task of humankind and yet, more than ever, there is today a most urgent need to use our knowledge to assess the states of the seas. This urgency

\footnotetext{
* Contribution of SCOR Working Group 115: Standards for the Survey and Analysis of Plankton

** Invited author
} 
derives from the detrimental impacts of loosing some of the benefits provided by the oceans, especially in countries whose coastal populations are socially and economically highly dependant on fishing and aquaculture, and from an ethical point of view.

Monitoring the oceans is one of the main activities of regional and global scientific programmes and networks, most of which are supported by international organizations such as the Scientific Committee on Oceanic Research (SCOR; http://www.jhu.edu/scor), the Intergovernmental Oceanographic Commission (IOC), the International Geosphere-Biosphere Programme (IGBP; http:// www.igbp.kva.se), and the International Council for the Exploration of the Sea (ICES; http://www.ices.dk). For example, the Global Ocean Observing System international programme (GOOS; http://www.ioc.unesco.org/goos), sponsored by IOC together with the World Meteorological Organization (WMO), the United Nations Environment Program (UNEP) and the International Council of Scientific Unions (ICSU), aims at developing a global network for the acquisition, integration, and distribution of ocean data that will generate the information and forecasts required by governments, industry, science and the public to deal with marine related issues, including the effects of the ocean upon climate. Most of the existing monitoring systems are concerned primarily with physical observations whereas those involving biological or ecological studies are fewer. The reason for this difference might be i) technological limitations for continuous or intensive sampling of a large part of the planktonic components, either by direct or remote means, and ii) the time-consuming analyses of large numbers of samples that could be obtained with intensive sampling equipment if traditional methods of analysis are applied (e.g., human visually-based microscopy).

Life in the oceans is an explicit or implicit subject of monitoring in some of the large international programmes/ networks sponsored by the above mentioned organizations through several projects or networks. Among them, the project ‘Global Ocean Ecosystem Dynamics' (GLOBEC; http://www.pml.ac.uk/globec) aims to understand the effects of global change on the abundance, diversity and productivity of marine populations. The network 'Census of Marine Life' (CoML; http://www.coml.org) aims to assess and explain the diversity, distribution, and abundance of life in the oceans. The project 'Integrated Marine Biogeochemistry and Ecosystem Research' (IMBER; http://www.imber.info) is focused on ocean biogeochemical cycles and ecosystems; it aims to provide a comprehensive understanding and an accurate predictive capacity of ocean responses to accelerating global change. The 'Global Ecology and Oceanography of Harmful Algal
Blooms’ programme (GEOHAB; http://ioc.unesco.org/ hab/GEOHAB.htm) fosters and promotes cooperative research directed toward improving the prediction of harmful algal bloom events. All these projects or networks have a strong emphasis on pelagic-planktonic components and require sustained programmes of observation.

Despite the relevance of monitoring to the above programmes/networks, current long-term (>30 years) international ocean monitoring programmes that deal with planktonic systems are still few, for example: i) the Continuous Plankton Recorder (CPR) survey at the Sir Alister Hardy Foundation for Ocean Science (SAHFOS, UK; http://www.sahfos.org), and ii) the Harmful Algal Bloom (HAB) programme at the IOC (http:// www.ioc.unesco.org/hab). At country level, there are a few more examples, the best representative of them being the California Cooperative Oceanic Fisheries Investigations (CalCOFI) in the United States (http:// www.calcofi.org). These programmes, and other existing plankton surveys (see review in Perry et al. 2004), provide data on the distribution and abundance patterns of plankton in the upper layers and are highly linked to current environmental concerns, including eutrophication, impact on fisheries, spreading of non-indigenous plankton species, changes in marine biodiversity, and global warming. In this context, SCOR created the Working Group on 'Standards for the Survey and Analysis of Plankton' (WG-115) whose aims were: i) to help develop standards for sampling, analysis and storage of data and samples obtained by high speed and extensive sampling systems, and ii) to assess current and future technological needs as a contribution to GOOS and GLOBEC. In order to accomplish these aims over a wide range of regions in the oceans and over the long term, the identification of the problems halting the advancements in monitoring and analysing planktonic systems is an essential process. Most of these problems relate, as in other aspects of ocean sciences, to the quantity and quality of the human resources dedicated to these studies in any given region or country and the extent to which the knowledge generated is considered of high relevance for sustained development in that region or country.

Well structured scientific and technical capacities are critically important for achieving the regional and global objectives of understanding the functioning of the oceans, conserving their health and resources, and predicting the impacts of climate change. Many international programmes related to ocean studies and monitoring, as well as those concerning global climate change, include 'capacity building' as a fundamental activity in order to achieve these objectives. Capacity building (CB) in the context of ocean monitoring and research describes the 
actions concerning the 'development, fostering and support of infrastructure, resources and relationships for ocean science and related systems and services, at individual, organizational, inter-organizational, regional and systems levels, contributing to the peaceful, socially distributed (equitable) and sustainable development of our societies' (IOC 2005). Other views of CB include 'assistance/transfer to developing countries' and 'northsouth flow of knowledge/assistance', terms that do not integrate the shared necessity of mankind regarding the protection and conservation of the oceans. There are, however, differences in capacity between countries and between regions in terms of the monitoring and analysis of planktonic systems and, therefore, improvements are more urgently required in the regions where knowledge of the oceans is least advanced.

The purpose of this document is to define the CB components which are essential for the success of the objectives of large-scale scientific programmes and initiatives dealing with monitoring and analysing planktonic communities in the oceans. These components include: a) training of students, technicians, and scientists, b) availability of platforms and instrumentation for timeseries sampling and sample analyses, and c) access to information systems and networking for the exchange of data and information. How these components could be included in specific CB actions or have been partially accomplished in the Latin-American region are here discussed.

\section{Elements of analysis}

a) Training of students, technicians, and scientists

Scientific capacity with regard to plankton monitoring and analysis includes both very basic needs related to knowledge of the structure of planktonic assemblages (e.g. taxonomy, functional groups, diversity) and more complex aspects linked to the dynamics of the pelagic systems (e.g. factors structuring the spatial distribution of planktonic communities, the trophodynamics and regeneration capabilities in pelagic systems, climatic and oceanographic processes which affect the plankton over large temporal scales). At the basic level, numerous research projects or programmes over many decades have lead to traditional taxonomic descriptions (e.g. phenotypically-based) of plankton communities in the oceans and to assessments of the distribution and abundance patterns of species, assemblages, and functional groups.

Traditional taxonomy has become an increasingly unfashionable subject of research on pelagic systems during the last three decades and expertise in taxonomic identification is today a rare attribute. However, during the last decade, it has been recognized that knowledge of the taxonomic composition of plankton assemblages is fundamental to the understanding of, for example, their role in ecosystem processes (e.g. carbon or nitrogen fluxes), the impact of climate change, diversity and environmental issues, and in the design of fisheries ecosystem-based management. At the same time, molecular techniques are increasingly being applied to the identification of micro-organisms and plankton in general (e.g. Deja et al. 2002, Bucklin et al. 2003). This phylogeny-based approach has lead to the explosive discovery of many new, microscopic, life forms and metabolic types in the oceans, forms which were undetectable by traditional technology. These results pose new challenges in terms of the understanding of the structure and functioning of pelagic systems since we still know very little about the spectra of biochemical, physiological, and behavioural abilities of marine microbes (Caron 2005), the coupling of their diverse metabolic pathways into our present concepts of marine food webs and the extent to which trophic modes such as mixotrophy (e.g. Stoecker 1998) influence the flux of matter and biogeochemical cycles in the oceans.

Several current international programmes which involve plankton studies/monitoring are confronted with the large diversity of life forms and, therefore, recognize the need to strengthen and expand the field of marine taxonomy through training, the development of new methodologies, and enhancements in the dissemination of information. An excellent example of sustained training in plankton taxonomy is the 'Advanced Phytoplankton Course (APC) - Taxonomy and Systematics’ (http:// www.szn.it/ apc8), which started in 1976 as a recommendation of the SCOR WG33 on 'Phytoplankton Methods' and ran its $8^{\text {th }}$ version at the Stazione Zoologica 'A. Dohrn', in Italy in 2005. No similar international courses exist on a regular basis and, even then, APC is not frequent enough to cover the training of a significant number of students, technicians, or young investigators in marine sciences. At a more specific level, the IOC has conducted training courses on harmful micro-algae (http:/ /ioc.unesco.org/hab/ courses.htm) since 1993; the aim is to improve the standards in harmful algae monitoring in IOC Member States by awarding certificates of competence in identification and enumeration of HAB cells to scientists and technicians attending the course. A recent example of a training initiative on plankton sampling, processing techniques, taxonomy, and data evaluation was undertaken in the Mauritius and the Seychelles region (South western Indian Ocean) by the Plymouth Marine Laboratory (United Kingdom) through 
a DEFRA (Department for Environment, Food and Rural Affairs) - Darwin Initiative - project (http:// darwin.defra.gov.uk). This type of CB action will allow the host nations to develop and sustain a long-term research and monitoring programme which will eventually be used to characterize the pelagic system in different regions, to provide assessments of changes in biodiversity and the effects of environmental fluctuations, and/or to design or apply improved management measures of marine resources. Initiatives such as all those mentioned above should be encouraged by world organizations dealing with the assessments of the state of the oceans in nations which still do not have monitoring programmes but are economically and socially dependant on marine resources.

In general terms, there are not enough international courses dealing with the training in traditional and new technologies for the monitoring and analysis of plankton communities. This includes recognition of organisms, autonomous collection/analysis of plankton samples, statistical analyses of data on the distribution of organisms and their association with environmental variables, etc. A part of these demands is provided by the internet, where numerous web pages contain an amazing amount of information on plankton related subjects (e.g. the 'Microbial Life - Educational Resources'; http:// serc.carleton.edu/microbelife/index.html). Also, there are some international initiatives which encourage the participation of students and young researchers in practical courses, workshops, and/or visiting fellowships in the area of advanced plankton monitoring and analysis. An example of international support for training on ocean observing systems, potentially including the monitoring and analysis of plankton, is the organization 'Partnership for Observation of the Global Ocean' (POGO; http:// www.ocean-partners.org), a group of several institutions involved in oceanographic observations, scientific research, operational services, education and training. As part of the latter, POGO-SCOR Visiting Fellowships for Oceanographic Observations are open to scientists, technicians, graduate students (Ph.D.) and post-doctoral fellows involved in oceanographic work at research institutions in developing countries and countries with economies in transition. These fellowships offer the opportunity to visit marine centres for short periods (1-3 months) to obtain training in the collection of oceanographic observations, and in data analyses and interpretation. Initiatives like this could greatly enhance human resource development in the field and deserve extended and sustained support at national and international levels. The IOC Capacity Building Programme also offers yearly conference travel and study grants to marine sciences students or professionals from developing countries to participate in scientific/technical conferences, workshops or meetings with a clearly defined ocean-oriented nature; priority is given to subjects directly relevant to IOC programmes.

b) Availability of platforms and instrumentation for timeseries sampling and sample analysis

One of the largest problems facing the monitoring of plankton in the oceans has been the lack of sustained support for long-term research/monitoring programmes, both at national and international levels. At the national level, the leading oceanographic programme is CalCOFI (1949-onwards), a partnership of the California Department of Fish and Game, the Fisheries Service at the US National Oceanic and Atmospheric Administration (NOAA), and the Scripps Institution of Oceanography (SIO) in the United States. CalCOFI is based on regular cruises which include measurements of the physical and chemical properties of the California Current System and estimates of the abundances of phytoplankton, zooplankton, and fish eggs and larvae, among others. At the international level, the CPR survey (started in 1931) is an outstanding programme, based at SAHFOS and coordinated by an international charity registered in the United Kingdom. This marine monitoring programme uses CPRs from volunteer observing ships (VOSs) and has been collecting plankton over many decades so as to provide a unique data set on the biogeography, ecology, and climate impacts on the structure of pelagic systems in the North Atlantic and the North Sea regions.

Extensive or intensive monitoring of planktonic systems demands a large investment of monetary and manpower resources but increasing automation in the technology can provide considerable saving of time and effort in the collection and analyses of samples. Modern technologies and new approaches have experienced an explosive growth during the last decade and, together with the existing resources for the long-term monitoring of plankton (e.g. CPR) and traditional equipment (e.g. plankton nets, pumps, and oceanographic bottles), provide a wide range of opportunities to greatly expand the knowledge of these systems. The array of sampling devices used for plankton monitoring in the oceans is quite large and the inter-comparison of different approaches (i.e. nets, acoustics, optical video-recorders) is a matter of recent development (see reviews in Harris et al. 2000, Wiebe \& Benfield 2003, Remsen et al. 2004). There are, however, large differences in the availability of sampling platforms and instrumentation for undertaking regular monitoring and concurrent analysis of plankton in the different regions of the oceans. In particular, the south- 
eastern Pacific and the south-western Atlantic regions are one of the least known of the world oceans in terms of their marine ecosystems.

Besides the financial constraints in using modern and automatic sampling devices for plankton monitoring in certain countries or regions, it is clear that the diversity of life forms in plankton systems is so wide that there is no existing equipment and/or analytical technique that is able to cover the full taxonomic range or diversity of life forms. For this reason, it could be important in some cases to identify the size spectra, taxa, or functional group of main interest for which a monitoring programme should be designed, a decision that is initially difficult to take the little knowledge of the system is available. Traditional methods of plankton collection involve taking discrete water samples (i.e. with bottles, nets, pumps), preservation (the kind of fixative to use for the smaller plankton fractions is still a matter of discussion in the literature) and storage, followed by microscopy analysis using human visually based identification and counting techniques. There are, however, at least two large problems associated with this practice: a) non-automated sampling, independently of the platform used, limits the number of observations/data obtained in the context of monitoring purposes (spatial and temporal scales), and b) non-automated analysis is time consuming and requires expertise in the recognition of specimens when there is a mixture of species/taxa in the plankton samples.

In understanding the need for the automation of sampling and analysis of plankton in the oceans, several attempts have been made to develop instrumentation to monitor plankton in near-real-time. Amongst the existing equipment, the CPR has been a most useful tool because it collects automatically samples of planktonic components over large areas (Warner \& Hays 1994). Some of its limitations are that most of the identifiable plankton is the one containing hard structures (e.g. diatoms, crustaceans, calcareous forms) in the micro- to meso-plankton size range and, in its original version, sampling is limited to a fixed depth $(10 \mathrm{~m})$ (Reid et al. 2003). In the context of the GOOS programme, the CPR approach has been recognised as a practical and cost effective way to obtain synoptic plankton data; CPR surveys now include extensive marine areas off USA and Canada, the Southern Ocean, and the Baltic Sea. There are, however, no CPR-based large time series studies/ monitoring programmes other than the one run by SAHFOS (1946 to present, on a monthly basis).

The large capability of the CPR as an automated plankton monitoring device is in contrast with the time involved in the analysis of the many samples it can gather and, today, these samples are being analyzed by a reduced number of experts in taxonomy. This limits a wider application of CPR as a time-series monitoring device in other regions, even if the equipment were to be made available for free use through international cooperation. In the last decade, however, there has been considerable progress in the automated counting and recognition of specimens in plankton samples based on image analyses (e.g. Sieracki et al. 1998, Culverhouse et al. 1996, Grosjean et al. 2004). Nevertheless, the compilation of a global reference data set on taxonomic units for the application of automated (machine) labelling systems awaits calibrations and standardization with taxonomic experts (Culverhouse et al. 2006a). Also, devices such as the CytoSense benchtop and CytoSub/CytoBuoy in situ flow-cytometers have been recently developed and could be widely applicable for the automated monitoring and/ or analysis of pico- to micro-plankton fractions (Dubelaar et al. 2004). Still under trial, the HAB-BUOY (http:// www.cis.plym.ac.uk/cis/projects/HABBuoy.html) is an in situ moored instrument for the detection of harmful algal blooms (HAB) in coastal waters (Culverhouse et al. 2006b). The FERRYBox (http://w3k.gkss.de/projects/ ferrybox), a fully automatic flow-through system with different sensors and analysers, is another example. In most plankton laboratories around the world, however, species identification is still largely dependant upon the use of human visually based microscopy.

In general, the technology being developed or available today for the sustained monitoring of plankton in almost real-time and covering a wide range of plankton forms/sizes is very promising and there is an urgent need to spread and transfer this technological knowledge and expertise around the world. For this reason, a strong programme of international cooperation is essential considering that extended plankton time series are still rare for many regions of the oceans. The largest investments should be on the purchase of automatic equipment and on the training of scientists and technical staff to run the devices for the collection and analysis of plankton samples; eventually, these actions will save time and with that will provide timely information where is required. At the same time, appropriate sampling protocols and inter-comparisons of instrumentation must be encouraged in all the cases when the information on plankton monitoring is to be globally scaled. It is clear, however, that all advances in the automation of instrumentation and analyses of plankton are necessarily based on the expertise of taxonomists and on the broad view of ecologists so as to design or improve machines that can recognize the various taxa or forms of life that are of ecological or biogeochemical relevance. 
c) Access to information systems and networking for the exchange of data and information

Plankton monitoring programmes commonly designed to detect changes in the pelagic system establish operational observing systems that routinely and continuously generate the targeted information. The design, implementation, and development of these systems should obviously be guided by the data and information needs/ priorities of the local researchers and users. The timely dissemination of the information generated provides a mean for opportune explanations and predictions of the changes occurring in the ecosystems. For this purpose, global databases on biological variability in the oceans are emerging. The 'Ocean Biogeographic Information System' (OBIS; http://www.iobis.org) of the CoML is an example; OBIS will provide global access to taxonomic, genetic, ecological and environmental information of the oceans. In plankton in particular, 'Census of Marine Zooplankton (CMarZ)' is a global survey of zooplankton biodiversity sponsored by the CoML and was launched in 2004 with funding from the Alfred P. Sloan Foundation. CMarZ plans a taxonomically comprehensive, geographically extensive survey of all holozooplankton groups by 2010. Also, 'The ZooGene database' contains molecular systematic, taxonomic, and biogeographical data on some zooplankton groups (http:// www.ZooGene.org).

Data from plankton monitoring programmes are also gradually becoming widely available through their institutional websites (i.e. CPR, CalCOFI, and the IOCICES-PICES Harmful Algae Event Data Base: HAE-DAT; BATS Zooplankton census: http://www.vims.edu/ bio/ zooplankton/BATS). In other cases, these data are contributed by researchers to world data centres such as the World Data Center System (WDC; http:// www.ngdc.noaa.gov/ wdc/wdcmain.html; World Ocean Database 2001: http://www.nodc.noaa.gov/OC5/WOD01/ pr_wod01.html), the COPEPOD global Plankton Database (www.st.nmfs.noaa.gov/plankton), the World Data Center for Marine Environmental Sciences (WDCMARE; www.wdc-mare.org), and the World Biodiversity Database (http://www.eti.uva.nl/tools/wbd.php).

Many countries or research institutions which could be important in reinforcing a global network on plankton monitoring because they are located at sites/regions of relevance from biogeographic, biogeochemical, environmental, economical or other points of view, do not have the resources, technologies or expertise to develop and implement an observing system or to contribute to the global network of information without considerable assistance (IOC 2003). Among the forms of assistance, there are today multiple possibilities for selflearning activities via open access to resources through the internet. In general, global networking has provided the means for closer interactions between geographically distant researchers and, thereby, supporting the collaboration when there is limited access to resources.

The amount of information now available on the internet is so large and of wide distribution that a great deal of time can be spent first in searching through the information before making use of it. Simple actions, such as the provision of a list of websites with the most relevant information on plankton monitoring and analysis, can be extremely useful for ample distribution amongst individuals/institutions that have less access to or are not aware of these facilities. An example of the diversity of websites that can be used for the recognition of planktonic organisms is presented in Table 1. Among these, Plankton*net has been established as a community source of information on marine micro-organisms (http://ebck.rd.awi-bremerhaven.de/protist/baypaul/microscope/ general/page_01.htm). The inaugural nodes will include the Alfred Wegener Institute (Germany), Station Biologique at Roscoff (France), University of Lisbon (Portugal) and the Kinneret Limnological Laboratory (Israel). Also, Micro*scope (http://starcentral.mbl.edu/ microscope/portal.php) is a community website that provides descriptions of all kinds of microbes and it links to other expert-sites on the internet. It is based at the Marine Biological Laboratory at Woods Hole Oceanographic Institution. As pointed out before, however, the appropriate use of these resources requires the establishment of standards and quality images of specimens for their accurate identification (Culverhouse et al. 2006a).

In terms of other traditional means for the dissemination of information, the quite recent electronic availability of many scientific journals in the field of planktonic studies, and in ocean sciences in general, has been a major step forward. The access, however, to published information in the field is still a big problem for some institutions/countries because of the large costs involved in the subscriptions to journals. In more general terms, a large effort is being made to have freely available on the internet research articles in all academic fields; this effort, known as the Budapest Open Access Initiative (http://www.soros.org/openaccess), should be strongly endorsed by scientists and institutions around the world and especially in Latin-America and developing countries in general. In the marine plankton field, some efforts have been made to solve part of this problem. For example, the 'Journal of Plankton Research' (http:// www.plankt.oxfordjournals.org), and the Oxford Journals 
Table 1

Examples of websites with information on plankton identification and image databases

Ejemplos de sitios en Internet con información sobre identificación de plancton y bases de datos con imágenes

\section{GENERAL PAGES INCLUDING PLANKTON}

Baltic Sea - Finnish Institute of Marine Research Harmful Plankton Project, UK waters - U. Liverpool ICES Identification Leaflets for Plankton Images of microscope

Information on algae

Image quest marine

Marine \& Atmospheric Research

Marine Bio-Plankton Images

MARBEE, U. College Dublin)

MARBEF - EU Network of Excellence

MarineBio.org: ocean life, biology \& conservation

Microbial description \& Taxonomy

Microplankton images

Plankton Image Library at SAHFOS

Micro*scope, Marine Biological Laboratory at WHOI Plankton Net - AWI

The Plankton Net; Plankton Ecology, Marine Biology

\& Biological Oceanography

The Tree of Life Web Project (ToL)

Zooplankton of the south western Indian ocean

\section{PROTISTS IN GENERAL}

Checklist of phytoplankton in the Skagerrak-Kattegat

- Dep. Marine Botany, Göteborg University

Images \& information

Protist image data

Photos \& Video of Protozoa

The origin \& evolutionary relationships of Protista

\section{CYANOBACTERIA}

Cyanosite

CILIATES

Planktonic Ciliate Project

Web links of ciliates

\section{RADIOLARIA}

General information

Microfossil image recovery

\section{DINOFLAGELLATES}

General information

DICANN Project

Dinoflagellates - Asian Natural Environmental

Science Center, University of Tokyo

DinoFlaj - Geological Survey of Canada (Atlantic)

Identifying Harmful marine Dinoflagellates -

Smithsonian Institution

\section{DIATOMS}

Algae image archive

Biovolumes of algal taxa: USGS NAWQA program California Academy of Sciences Diatom Collection.

Great Lakes Waterlife Photo Gallery

\section{COPEPODS \& AMPHIPODS}

Database on amphipod literature.

Diversity \& geographic distribution - marine copepods

World of Copepods - Smithsonian National Museum of Natural History. http://www.fimr.fi/en/itamerikanta/tietoa/eliot.html

http://www.liv.ac.uk/hab

http://www.ices.dk/products/idleaflets.asp

http://www.microscopy-uk.org.uk/

http://www.algaebase.org

http://www.imagequest3d.com/stock/

http://www.cmar.csiro.au/

http://www.biosci.ohiou.edu/faculty/currie/ocean/links.htm

http://www.ucd.ie/zoology/marbee/index.htm

http://www.marbef.org/

http://www.marinebio.com/

http://biology.kenyon.edu/Microbial_Biorealm/taxa.html

http://bioloc.coas.oregonstate.edu/SherrLab/Microplankton\%20images.html

http://192.171.163.165/pil/plankton image database homepage.htm

http://starcentral.mbl.edu/microscope/portal.php

http://e-bck.rd.awi-bremerhaven.de/protist/baypaul/microscope/general/page 01.htm

http://www.biosci.ohiou.edu/faculty/currie/ocean

http://www.tolweb.org

http://www.pml.ac.uk/pml/sharing/zooplankton.htm

\section{http://www.marbot.gu.se/SSS/SSShome.htm}

http://www.ucmp.berkeley.edu/

http://megasun.bch.umontreal.ca/protists/protists.html

http://wolfbat359.com/protozoa.html

http://users.rcn.com/jkimball.ma.ultranet/BiologyPages/P/Protists.html

http://www-cyanosite.bio.purdue.edu

http://www.liv.ac.uk/ciliate/site/index.htm. http://ebiomedia.com/teach/ciliatesLinks.html

http://www.radiolaria.org

http://www.ucl.ac.uk/GeolSci/micropal/radiolaria.html

http://biology.kenyon.edu/Microbial Biorealm/eukaryotes/dinoflagellata/dinoflagellata.ht ml\#classif

http://dist.unige.it/dicann/ImageDB/main.html

http://dinos.anesc.u-tokyo.ac.jp

http://gsca.nrcan.gc.ca/pubprod/dinoflaj/index_e.php

http://www.nmnh.si.edu/botany/projects/dinoflag/index.htm

http://www.bgsu.edu/departments/biology/facilities/algae/html/Image_Archive.html http://diatom.acnatsci.org/nawqa/2001biovol.asp http://www.calacademy.org/research/diatoms/index.html http://www.glerl.noaa.gov/seagrant/GLWL/Algae/DominantAlgae.html\#Species

http://www.imv.uit.no/ommuseet/enheter/zoo/wim/amp_main.html

http://copepodes.obs-banyuls.fr

http://www.nmnh.si.edu/iz/copepod/ 
in general, have considered a reduced rate access or free subscription for developing countries, in conjunction with the International Network for the Availability of Scientific Publications (INASP); this opportunity is available to established not-for-profit educational institutions from qualifying countries and provides access to an online collection of the journals. Furthermore, through the Oxford Open Access initiative, authors of accepted papers are given the option of paying an Open Access publication charge to make their paper freely available online immediately via the journal website. Also, the journal 'Marine Ecology Progress Series' (http://www.intres.com/journals/meps) has recently provided free electronic access to the full text of articles 5 years after their publication. Moreover, this journal holds and provides free access to the CPR Atlas of the North Atlantic Ocean 1958-1999 (http://www.int-res.com/journals/meps/ cpr-plankton-atlas-2004).

\section{Capacity building requirements and examples from Latin-America}

Research and monitoring of the ocean systems and resources in the countries which surround the South American coasts has been strongly driven by the economical impacts related to the exploitation of fishing resources and, more recently, to the expansion of aquaculture activities. In particular, Peru and Chile contribute largely to the total global fish captures and Chile is a world leader in salmon farming. Compared with other regions, the eastern South Pacific waters on the west coast of South America are perhaps the least explored in the world oceans and the coverage of ocean observing systems is dramatically poor compared with the social and economic relevance of the resources it provides. In this context, a review of some of the existing requirements and actions of capacity building related to plankton monitoring and analysis is presented in this section, considering the elements discussed above.

\section{a) Training of scientists and technicians}

Marine science undergraduate and graduate programmes in the Latin-American region are scarce, especially when considering that most South-American countries face the oceans and make full use of their resources. Until recently, most of the training activities in this field have emphasized marine biology and biological oceanography but even then, there are not many internationally recognized researchers studying plankton assemblages in the region. There is one good example of sustained training activity in the region: the UNESCO Chair - Oceanography School at the Universidad de Concepción (Table 2) which promotes and provides partial financial support for the training of students and young researchers in oceanography. Besides the extraordinary success of this initiative, the main drawbacks are that there is no set of permanent courses and, for the most part, these courses have been confronted with the scientific shortcomings that have limited our knowledge of the oceans in this region (e.g. lack of sustained ocean observing systems; shortage of expertise in taxonomy; limited access to oceanographic platforms and to scientific information systems). CB initiatives to create 'Regional schools of oceanography' have been an aspect of long-term discussion in international panels linked to ocean research (e.g. SCOR), yet no action has been seriously planned for this region. There is, however, a current networking educational project which can provide the first steps to achieve this kind of action, the details of which are given in Table 3.

Specific areas of scientific and technical training which could contribute to enhance the resource formation related to plankton monitoring and analysis in the LatinAmerican region include, among others: a) time series sampling and data analysis, b) multivariate analyses of plankton communities in relation to the environmental conditions, c) molecular techniques applied to diversity studies, d) classical plankton taxonomy at different levels, e) sampling and sample analysis techniques applicable to plankton studies in general, and f) operation and maintenance of automatic monitoring/analysis equipment. No doubt, an international and regional effort to sustain a formal programme of training in these subjects will bring benefits not only in terms of a better scientific understanding of the oceans in the region but also in the economic and social aspects of the countries, and in improving the global assessments of the role of the oceans in climate change.

b) Availability of platforms and instrumentation for timeseries sampling and analysis

One of the large problems in Latin-America is the lack of infrastructure and instrumentation for monitoring the oceans in general and the plankton in particular. Research vessels are few in most of the countries and operate mainly in coastal waters. In Chile, for example, there are only two research vessels that are able to work in coastal and oceanic areas with a certain autonomy. Their use, however, is coordinated by governmental agencies that have to fit all the demands associated with marine sciences and oceanography (hydrography, oceanography, geophysics, fisheries, red-tides, and others) along the extensive ocean area off Chile. In most countries of South-America, shiptime funding agencies are highly oriented to fisheries monitoring and most of these programmes do include a plankton component. Even then, long-term plankton time 
Table 2

Example of training activities in oceanography in the Latin-American region

Ejemplo de actividades de entrenamiento en oceanografía en la región Latinoamericana

\section{UNESCO/IOC Chair in Oceanography and Coastal Management, Universidad de Concepción (Chile)}

UNESCO/IOC Chair in Oceanography and Coastal Management (Chair holders: Dr. J. Stuardo, 1993-May 2002; Dr. S. Pantoja, from May 2002) was established at the Universidad de Concepción (Chile) in 1993. Focused on advanced training, the Chair is based on the graduate programme in Oceanography of the Universidad de Concepción. It provides international annual intensive courses that serve the interests and needs of specialization in oceanography in the whole Latin American Region. On the average the courses have the duration of 2-3 weeks of well-planned, daily activities to keep close contact between students and lecturers. The courses credited as formal specialized learning activities, are directed to the graduates (Chilean and foreigners) registered at the graduate programmes in Oceanography, Universidad de Concepción, to graduates from other related programmes existing at the University and to young researchers, academics and professionals working in other Chilean and Latin American Universities, research institutions and governmental bodies conducting oceanographic research.

Annually the Chair provides travel grants to trainees from the region (outside Chile). As a result of the benefits of the graduate programmes in Oceanography at the Universidad de Concepción and the International Courses organized by the Chair serve the interests of applicants from Mexico in the north to Argentina and Chile in the south. Further, Latin American (non-Chilean) graduates who enter the doctoral programme were annually awarded grants under a fellowship programme offered by the German Academic Exchange Service (DAAD), though this was recently stopped (2006). The $\mathrm{PhD}$ students registered up to 2002 belong to the following countries: Ecuador, Peru, Colombia, Argentina, Uruguay, Costa Rica, Nicaragua, Cuba and Chile.

In addition to IOC and the $\mathrm{DAAD}$, as well as national funding, equally remarkable has been the support provided by the South African Foundation for Research Development, the Swedish Institute, and the Embassies of Canada, France and Switzerland. Scientists from Japan and Australia were able to raise their own funds to contribute to the Chair activities. All in all, the positive attitude of the international oceanographic community to become part of the Chair's programme has to be stressed. A high demand against the few available fellowships is a clear indicator that the needs of advanced education and training in the Region are overwhelming, requiring prompt solutions by the individual countries and ad hoc international programmes. The fact remains, however, that there are very few attempts within the Region to cope with these problems. Of major relevance is the high interest of the international academic community to participate actively in the development of Oceanography in developing countries and the realization that individual efforts through any of these intensive courses has a profound effect in the overall development of marine science in Chile and Latin America in general.

It is hoped that the international backing of the relevant bodies like SCOR and IOC to the Chair's ongoing programme, and its very positive impact in the development of oceanography in Latin America, will help to guarantee its continuation for at least five more years. The great demand for the international courses is a clear indication of the lack of any similar undertaking at the sub-regional and regional levels. Furthermore, the experience and support of UNESCO/IOC is considered fundamental to overcome some of the partial shortcomings in the original twinning objectives of the Chair.

Extract (with small modifications) from the IOC webpage: Training and Education and Mutual Assistance in Marine Sciences (TEMA): http://ioc.unesco.org/tema/concepcionchair.htm; prepared by Sonia Guiraud (s.guiraud@unesco.org) 
Table 3

Example of networking for improving the education in oceanography in Latin-America

Ejemplo de redes de conexión para el mejoramiento de la educación en oceanografía en Latinoamérica

\section{Programme ALFA - LATIN-AMERICA-ACADEMIC TRAINING Exchange Programme between Universities of the European Union and Latin-America}

European Commission - EuropeAid - Cooperation Office - Latin-America Directorate

ALFA (América Latina - Formación Académica) is a programme of cooperation between higher education institutions of the European Union and Latin-America (http://europa.eu.int/comm/europeaid/projects/alfa). Participant countries are the Member States of the European Union and the following 18 countries of LatinAmerica: Argentina, Bolivia, Brazil, Chile, Colombia, Costa Rica, Cuba, Ecuador, El Salvador, Guatemala, Honduras, Mexico, Nicaragua, Panama, Paraguay, Peru, Uruguay and Venezuela

In the context of Oceanography, a project was presented (2003) to the Sub-Programme A (Cooperation for Institutional and Academic Management), entitled "Latin-America-Europe School of Oceanography (Network of Latin-American and European Institutes for Graduate Education in Oceanography (LA-EUSO)). This project was approved for the 2005-2006 period and its objectives are: 1.- To innitiate network cooperation between LatinAmerican and European educational institutions, 2.- To define agreements on cooperation in institutional management and mobility; and 3.- To establish the basis for a sustainable network of cooperation and a complementary project on scientific research.

This project started in 2005 and involves the following instituions in Europe: University of Gotenburg (Sweeden), Kiel University (Germany), Plymouth University (United Kingdom), and Universidad de Vigo (Spain), and in Latin-America: Universidad de Costa Rica (Costa Rica), Universidad de Bogota Jorge Tadeo Lozano (Colombia), Escuela Nacional Técnica del Litoral (Ecuador); Universidad Nacional Agraria La Molina (Peru), and Universidad de Concepción (Chile). Part of the activities involved in this project include the expansion of institutions joining this network. The main activities of the project are oriented to establish or expand the graduate programmes in Oceanography to benefit mainly students from Latin-America and include: 1.- Curriculum development and teaching management; 2.- Certification of courses and degrees; 3.- Curriculum harmonization; and, 4.Administrative management.

The unit coordinating this project is the Graduate Programme of Oceanography at the Department of Oceanography, Universidad de Concepción (Coordinator: Tarcisio Antezana: antezana@udec.cl). Previous experiences of this institution with international cooperation links include: 1.- German Academic Exchange Service (DAAD), supported for more than 10 years a programme of scholarships for Latin-American students attending the Graduate Programme of Oceanography at the Universidad de Concepción; 2.- Woods Hole Oceanographic Institution, Fundacion Andes (Chile), and the Universidad de Concepción have supported for the last 5 years a permanent programme of academic cooperation focused on Graduate Education in Oceanography in Chile; 3.- The Universidad de Concepción has been the recipient of a catedra UNESCO in Environmental Studies and Oceanography at the Universidad de Concepción, for several years; 4.- Most faculty members of the Dept. of Oceanography have or are currently participating in several international projects or organizations (i.e. JGOFS, GLOBEC, POGO, CoML, and several EU framework projects); 5.- The institution participates in numerous academic agreements with foreign well recognized oceanography institutions (i.e. Max Planck Institute for Microbiology, University of Gothenburg, Woods Hole Oceanographic Institution, Scripps Institution of Oceanography, and others). 
series data are few (Table 4; Perry et al. 2004). This is surprising considering, among others, strong effects of climatic variability (e.g. El Niño phenomenon) in a region with one of the largest fisheries in the world.

Instrumentation devices for monitoring plankton in the South-American region are mainly of the traditional kind (oceanographic bottles for smaller plankton and simple nets for larger zooplankton). Also, for the most part, the smaller planktonic components have been undersampled in many surveys and emphasis has been given to the micro-phytoplanktonic component. Equipment for the analysis of plankton samples is, in general, basic (e.g., inverted, epifluorescence, and light microscopy) whereas advanced equipment (e.g., image analysis systems) is scarce. Sustained support of plankton time series in the region is rare, as in most coastal countries in the southern hemisphere. A better situation is not foreseen in the near future unless major cooperative efforts are made on the automation of sampling and analyses. In recent times, a few laboratories in this region have been able to acquire advanced equipment for plankton studies, including multinets, optical and acoustic devices, oceanographic buoys with fluorescence probes, flow-cytometers, microscopy for molecular analyses, etc. (e.g. the COPAS Centre at the Universidad de Concepción) but, undoubtedly, there is a long way to go yet.

In an ideal situation, the creation of oceanographic resource centres in regions linked to the South-western Atlantic and the South-eastern Pacific oceans, could provide a big step in the accomplishment of CB actions on plankton monitoring and analysis. These resource centres might not only provide a platform for the use of modern equipment via joint projects in each region but also could act as units for the calibration of the equipment and the standardization of plankton sampling and analyses. At a more general level of ocean monitoring, so far excluding plankton, countries along the western coast of South-America (Peru and Chile) have recently developed networks based on buoys and tide gauges in order to follow changes in coastal waters, especially those associated with the effects of El Niño and La Niña events, and to improve their forecasts. There are prospects of combining these networks with the observing systems from Ecuador and Colombia into a future South-eastern Pacific GOOS; at present, IOC is discussing this possibility with the Permanent Commission for the South Pacific (CPPS).

c) Access to information systems and networking for the exchange of data and information

Databases and networks related to plankton studies in the Latin-American region are very scarce. A general effort at gathering information for the region and/or establishing information networks is being made in a few cases (Table 5). In general, samples and data derived from different surveys in the region are mostly not in the public domain and their owners have, in general, very little interaction with the scientific community so as to allow full use of the information available. Examples of information dissemination related to plankton taxonomy and diversity in the region are dispersed in the scientific literature and institutional reports. Perhaps the only good example of data compilation on planktonic forms in the region is provided by the Atlas of South Atlantic Zooplankton (Boltovskoy 1981, 1999) which covers most of the holoplanktonic meso- to macro-zooplankton species for the area. Even then, it is extremely hard to find a copy of this reference material in many South-American plankton laboratories and no such document exists for the southeastern Pacific Ocean. Also, literature compilations on methods applicable to the sampling and analysis of plankton are few (Kemp et al. 1993, Harris et al. 2000). A step towards improving the dissemination of methods applicable to plankton studies in the South-American region is the preparation of a book, resulting from the collaboration of Argentinian and Chilean researchers (Alder \& Morales in press; Table 6), which includes several protocols, examples of calculations, and specific materials used in plankton studies. This handbook (in Spanish) is by no means a complete guide to all types of methods but should be useful for improving the study of less well known groups/taxa and rate processes in the Latin-American region.

In terms of collaborative networks, one of the largest existing international initiatives to understand the structure and dynamics of the coastal systems off SouthAmerica, the 'Climate variability and El Niño Southern Oscillation: implications for natural coastal resources and management' project (CENSOR; http://www.censor.name/ pagev2) aims to enhance the detection, compilation and understanding of El Niño and La Niña effects on coastal marine environments and resources in the region. This project involves six European and Latin-American institutions and is mostly financed by the programme 'Integrating and Strengthening the European Research Area - Specific Measures in Support of International Cooperation (INCO)' of the European Commission (under the 6th Framework as Specific Targeted Project -INCOCT2004-511071). At a more general level, the 'International Institute for Global Change Research' (IAI; http://www.iai.int) is an intergovernmental organization supported by nineteen countries in the Americas dedicated to pursuing the principles of scientific excellence, international cooperation, and the open exchange of 


\section{Table 4}

\section{Examples of plankton time series efforts in South America}

Ejemplos de esfuerzos de series de tiempo en Sudamérica

\section{Argentina}

a) Bahía Blanca estuary (38 $\left.45^{\circ} \mathrm{S} 62^{\circ} 20^{\prime} \mathrm{W} ; 1974-1998\right)$ by IADO (Instituto Argentino de Oceanografia). Its main objective is to relate various aspects of chemical oceanography to coastal primary production and eutrophication processes in the area. Sampling is performed every 15 days. Variables measured at these sites include: 1) phytoplankton species abundance, 2) chlorophyll-a concentration, 3) temperature and salinity, 4) irradiance, 5) nutrient concentrations, 6) dissolved oxygen, 7) gross and net primary production, and 9) others such as turbidity, tidal level, and meteorological conditions (Lutz et al. 2005).

b) Bahía Engaño ( $43^{\circ} \mathrm{S} 65^{\circ} \mathrm{W}$; Chubut Province), started in 2000 by EFPU (Estación Fotobiológica Playa Unión). It aims to assess the impact of solar ultraviolet radiation (UV) on the primary productivity of natural phytoplankton assemblages. The station is sampled every month, the data obtained including: 1) phytoplankton species abundance, 2) chlorophyll-a concentration, 3) temperature, 4) irradiance, 5) absorption spectra of phytoplankton and detritus, primary production, and 6) UV-absorbing compounds on phytoplankton (Lutz et al. 2005).

c) Coastal station off Buenos Aires (EPEA: Estación Permanente de Estudios Ambientales; 38²8'S, 57²41'W), sampled since 2000, under the project DiPlaMCC (Dinámica del Plancton Marino y Cambio Climático) based at INIDEP (Instituto Nacional de Investigación y Desarrollo Pesquero). The main aim is to understand how variations in the dynamics and diversity of plankton communities are linked to climate change. The station is sampled monthly and the project is expected to run for about 10 years. The data being gathered include: 1) phytoplankton species abundance, 2) chlorophyll-a concentration, 3) temperature, density, and salinity (CTD), 4) irradiance, 5) absorption spectra of phytoplankton, detritus, and colored dissolved organic matter, 6) nutrient concentrations; 7) dissolved oxygen, 8) ultra-phytoplankton (<5 m), and 9) bacterioplankton (Lutz et al. 2005).

\section{Chile}

a) Upwelling area off northern Chile time series (1965 - continued), run by IFOP (Instituto de Fomento Pesquero). It holds one of the few and longest time series of zooplankton for the upwelling area off Chile; nevertheless, samples are kept in poor conditions and the only data common to the whole series is displaced volume and ichthyoplankton composition (IFOP reports; Loeb \& Rojas 1988).

b) Short time series (1991-2003) on copepod species have been obtained at a coastal site off Mejillones (Escribano \& Hidalgo 2000).

c) Upwelling area off central-southern Chile (2002 - continued), run by the COPAS (Centro de Investigación Oceanográfica en el Pacífico Sur-oriental), at the Universidad de Concepción. This is a multi-disciplinary time series based at a fixed shelf station $\left(36^{\circ} \mathrm{S}\right)$, sampled on a monthly basis. The plankton data includes abundances of pico- to macro-plankton fractions, primary production and respiration, plus physical and chemical variables. Since 2004, this time series studies has also been supported by FIP (Fondo de Investigación Pesquera) (Escribano et al. 2005).

\section{Peru}

In the field of research on plankton, IMARPE (Instituto del Mar del Perú), UNMSM (Universidad Nacional Mayor San Marcos), and UNSAA (Universidad San Agustín) are developing traditional lines of investigation such as the monitoring of water mass indicator species, the study of red tides and phytoplankton potentially toxic to filterfeeding organisms, and the assessment of the spatial and temporal distribution of ichthyoplankton. The development of innovative technologies for assessing the behavior and dynamics of biological communities has recently began with the deployments, by IMARPE, of floating, monitoring platforms for studying succession in plankton and nekton populations (Tarazona et al. 2003). IMARPE holds a zooplankton time series (1964 - continued; seasonal) off the Peruvian coast and continental shelf (Carrasco \& Lozano 1989, IMARPE reports). 
Table 5

Examples of scientific projects/networks that potentially contribute with data/information related to plankton monitoring and analysis in the Latin-American region

Ejemplos de proyectos/redes de conexión científicas que potencialmente contribuyen con datos/información relativa al monitoreo y análisis de blancton en la región Latinoamericana

\section{1) ANTARES}

With the support of the Inter-American Institute for Global Change Research (IAI), the International Ocean Colour Coordinating Group (IOCCG), and the Partnership for Global Ocean Observations (POGO), the South-American network "Antares" has been recently established (2003). The activities of this network can be followed at www.antares.ws. The main objective of the network is the study of the long-term changes in coastal ecosystems around South-America as to distinguish between natural variability and external perturbations (anthropogenic effects). To achieve this, members and the general public share data obtained from coastal stations and satellites (temperature and chlorophyll) in the region. Participating countries include: Argentina (Instituto Nacional de Investigación y Desarrollo Pesquero; Estación de Fotobiología Playa Unión; Instituto de Astronomía y Física del Espacio), Brazil (Universidade de Sao Paulo - Instituto Oceanográfico; Eiras Fundaçao - Universidade Federal do Rio Grande), Canada (Bedford Institute of Oceanography), Chile (Programa Regional de Oceanografia Física y Clima - Universidad de Concepción), Peru (Instituto del Mar del Perú), USA (Scripps Institution of Oceanography; Institute for Marine Remote Sensing - College of Marine Science - University of South Florida), and Venezuela (Fundación La Salle EDIMAR; Universidad Simón Bolívar). Coordinator: Vivian Lutz, Instituto Nacional de Investigación y Desarrollo Pesquero (INIDEP), Argentina (vlutz@inidep.edu.ar).

\section{2) OBIS}

The Ocean Biogeographic Information System (OBIS), the information component of the Census of Marine Life (CoML), includes $>1000$ researchers in 73 nations engaged in a 10-year initiative to assess and explain the diversity, distribution, and abundance of life in the oceans - past, present, and future. OBIS is a web-based provider of global geo-referenced information on marine species. The SOUTH PACIFIC SUB-NODE, created in 2005, covers the tropical and subtropical areas in the eastern South Pacific and it is sponsored by the Center for Oceanographic Research in the eastern South Pacific (COPAS; http://copas.udec.cl), Universidad de Concepción. Partner Institutions are: Instituto Oceanográfico de la Armada (INOCAR) - Ecuador, Universidad de San Marcos - Peru, Instituto del Mar del Perú (IMARPE) - Peru, Museo de Historia Natural - Chile, Universidad Arturo Prat de Iquique - Chile, Universidad de Antofagasta - Chile. Funding Source: Alfred P. Sloan Foundation; RON Manager: Ruben Escribano (rescribano@udec.cl); Technical Manager: Francisco Godoy (fgodoyf@udec.cl). Other sub-nodes in the South-American region are the Southern ocean (Argentina) and the tropical and subtropical South-west Atlantic (Brazil).

\section{3) ERFEN}

The programme ERFEN (Estudio Regional del Fenómeno El Niño), created in 1974, is sponsored by the Comisión Permanente del Pacífico Sudeste (CPPS; http://www.cpps-int.org) and it is ruled by a legal protocol agreed by the member countries (Colombia, Ecuador, Chile, and Peru). It is designed to monitor the meteorological and oceanographic conditions in relation to the fisheries-biological consequences of El Niño phenomenon. Currently, the member countries coordinate an annual and simultaneous cruise in the eastern South Pacific region, financed by governmental agencies. This series started in 1998 and so far constitutes the most extensive and sustained biooceanographic expedition in the region. The CPPS also produces a periodic climatic bulletin with regional and extra-regional prognostic information. ERFEN activities are supported by more than 22 scientific institutions in the member countries. It is expected that data gathered under ERFEN (the administration and management of which is still in the planning process) will contribute to GOOS under the recent creation (2005) of the Regional Alliance for the South-East Pacific (GRASP:GOOS; http://ioc3.unesco.org/odincarsa); this initiative is at the stage of developing its Strategic and Actions Plans. Also related to the El Niño theme, the CIIFEN (Centro Internacional para la Investigación de El Fenómeno El Niño; http://www.ciifen-int.org) is a regional institution created in 2003 and dedicated to the promotion of basic and applied research related to the improvement of the understanding and early warning of the phenomenon and climatic variability in the region. It is recognized as an information centre and network, was born as a United Nations resolution, and it is sponsored by the World Meteorological Organization, the EIRD (Estrategia Internacional para la Reducción de Desastres), and the government of Ecuador. 


\section{Table 6}

Example of initiatives to disseminate information on sampling and analytical methods applicable to the study of plankton in the South-American region

Ejemplo de iniciativas para diseminar información sobre métodos de muestreo y análisis aplicables a estudios de plancton en la región sudamericana

\section{Manual de métodos para el estudio de los sistemas planctónicos marinos V.A. Alder and C.E. Morales}

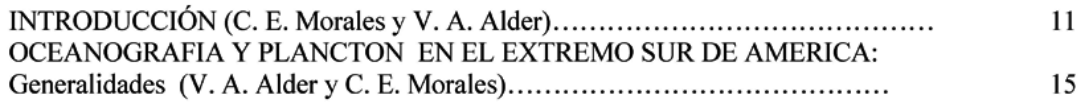

PARTE I - ESTRUCTURA

1. PICOPLANCTON (V. A. Alder, L. A. Cuevas, C. Franzosi)

Generalidades

1.1 Muestreo

1.2 Análisis de muestras

1.3 Bibliografía

2. NANOPLANCTON (L. A. Cuevas, V. A. Alder, C. Franzosi)

Generalidades

2.1 Muestreo

2.2 Análisis de muestras

2.3 Bibliografía

3. MICROPLANCTON y PRODUCTOS ZOOPLANCTÓNICOS (V. A. Alder y H.E. González) Generalidades

3.1 Muestreo

3.2 Análisis de muestras

3.3 Bibliografía

4. MESOZOOPLANCTON (M. Sabatini, R. Escribano, P. Hidalgo)

Generalidades

4.1 Muestreo

4.2 Análisis de muestras

4.3 Bibliografía

PARTE II - PROCESOS

5. INGESTION Y CONSUMO (C. E. Morales, C. Vargas, D. Böttjer)

Generalidades

5.1 Ingestión y consumo en micro-zooplancton

5.2. Ingestión y consumo en meso-zooplancton

5.3 Bibliografía

6. METABOLISMO (C.E. Morales y M.A. Varas)

Generalidades

6.1 Respiración

6.2. Excreción

6.3 Bibliografía

7. CRECIMIENTO, DESARROLLO, FECUNDIDAD Y PRODUCCIÓN DEL

MESOZOOPLANCTON (R. Escribano, M. Sabatini, P. Hidalgo)

Generalidades

7.1 Tasas de crecimiento

7.2 Producción secundaria

7.3 Bibliografía

\section{APENDICES}

Apéndice I. Microscopía de Fluorescencia (V. A. Alder) ......................... 251

Apéndice II. Unidades internacionales (UI): una guía básica (A. Davies)......... 
scientific information to increase the understanding of global change phenomena and their socio-economic implications. It provides opportunities for collaborative research projects, networking, and training.

\section{Concluding remarks}

In general, it appears that the opportunities for CB associated with training, access to information, and networking activities related to plankton studies in the Latin-American region, with the collaboration of oceanographic institutions of excellence in the world, have never been so extensive and promising as during the present decade. There is a strong need, however, to develop and maintain a network of time-series monitoring stations in the region, operated at national levels, in order to identify the scientific, economic, and social questions/ problems and to provide assessments/predictions related to oceans and their resources and services. Regional and international efforts should be devoted to the promotion of this line of action since there is already a large human resource capability in the region for developing sustained plankton monitoring programmes and networking with world data centres. In addition, modern and automated systems for plankton sampling and analysis (including platforms and equipment) are desirable in order to reduce the costs of maintaining these time series. The availability of plankton taxonomists and the maintenance of plankton reference samples in the region are similar to those in other countries over the world and so stronger opportunities should be coordinated by international, regional, and/or national agencies. To define all of these needs and to find their solutions, however, it would be important to establish the aims of these time series. No doubt, marine biodiversity conservation, natural resource availability, and the impacts of climate change in the oceans are of general human relevance in this region and elsewhere in the world.

\section{Acknowledgments}

This compilation and analysis is a result of the opportunity given to participate in the SCOR WG 115: Standards for the Survey and Analysis of Plankton. I have the most wonderful memories of our meetings and I thank all its members and Dr. Ed Urban at SCOR for that. Also my gratitude to the reviewers (including Dr. A. G. Davies) of earlier versions of this non-traditional manuscript; their patience to read and correct it is admirable.

\section{Literature cited}

Alder VA \& CE Morales. In press. Manual de métodos para el estudio de los sistemas planctónicos marinos. 267 pp. Editorial EUDEBA, Buenos Aires.
Béjà O, MT Suzuki, JF Heidelberg, WC Nelson, CM Preston, T Hamada, JA Eisen, CM Fraser \& EF DeLong. 2002. Unsuspected diversity among marine aerobic anoxygenic phototrophs. Nature 415: 630-633.

Boltovskoy D. 1981. Atlas del Zooplancton del Atlántico Sudoccidental y métodos de trabajo con el zooplancton marino. Instituto Nacional de Investigación y Desarrollo Pesquero (INIDEP), Mar del Plata. Publicación Especial: 1-938.

Boltovskoy D. 1999. South Atlantic Zooplankton. Volumes 1 \& 2: 1-1706. Backhuys Publishers, Leiden.

Bucklin A, BW Frost, J Bradford-Grieve, LD Allen \& NJ Copley. 2003. Molecular systematic assessment of thirtyfour calanoid copepod species of the Calanidae and Clausocalanidae using DNA sequences of mtCOI and nuclear 18S rRNA. Marine Biology 142: 333-343.

Caron DA. 2005. Marine microbial ecology in a molecular world: what does the future holds? Scientia Marina 69 (Suppl.): 97-110.

Carrasco S \& O Lozano. 1989. Seasonal and long-term variations of zooplankton volumes in the Peruvian sea, 1964-1987. In: Pauly D \& I Tsukayama (eds). The Peruvian Upwelling Ecosystem: Dynamics and Interactions. ICLARM Conference Proceedings 18: 82-85.

Culverhouse PF, R Williams, B Reguera, RE Ellis \& $\mathbf{T}$ Parisini. 1996. Automatic categorisation of 23 species of dinoflagellate by artificial neural network. Marine Ecology Progress Series 139: 281-287.

Culverhouse PF, R Williams, MC Benfield, PR Flood, AF Sell, MG Mazzocchi, I Buttino \& ME Sieracki. 2006a. Automatic image analysis of plankton: future perspectives. Marine Ecology Progress Series 312: 297-309.

Culverhouse PF, R Williams, B Simpson, C Gallienne, B Reguera, M Cabrini, S Fonda-Umani, T Parisini, FA Pellegrino, Y Pazos, H Wang, L Escalera, A Moroño, M Hensey, J Silke, A Pellegrini, D Thomas, D James, MA Longa, S Kennedy \& G del Punta. 2006b. HAB Buoy: a new instrument for in situ monitoring and early warning of harmful algal bloom events. African Journal of Marine Science 28: 245-250.

Dubelaar GBJ \& PJF Geerders. 2004. Innovative technologies to monitor plankton dynamics. Scanning Flow Cytometry: A new dimension in real-time, in situ water quality monitoring. Sea Technology 45(8): 15-21.

Escribano R \& P Hidalgo. 2000. Influence of El Niño and La Niña on the population dynamics of Calanus chilensis in the Humboldt Current ecosystem of northern Chile. ICES Journal of Marine Science 57: 1867-1874.

Escribano R, L Castro, G Daneri, L Farias, H Gonzalez, CE Morales, O Pizarro \& S Rosales. 2005. Monitoreo de las condiciones bio-oceanográficas en la VIII Región, año 2004. Informe final, Proyecto FIP No 2004-20: 1-154.

Grosjean P, M Picheral, C Warembourg \& G Gorsky. 2004. Enumeration, measurement, and identification of net zooplankton samples using the ZOOSCAN digital imaging 
system. ICES Journal of Marine Science 61: 518-525.

Kemp P, B Sherr, E Sherr \& J Cole. 1993. Handbook of Methods in Aquatic Microbial Ecology. 777 pp. Lewis Publishers, Florida.

Harris RP, PH Wiebe, J Lenz, HR Skjoldal \& M Huntley. 2000. ICES Zooplankton Methodology Manual. 684 pp. Academic Press, San Diego.

IOC. 2005. Guidelines on Best Practices in Capacity-Building. $23^{\circ}$ IOC Assembly, Item 4.7.2. version 1: 1-30.

Loeb V \& O Rojas. 1988. Interannual variation of ichthyoplankton composition and abundance relations off northern Chile, 1964-83. Fishery Bulletin 86: 1-24.

Lutz VA, EE Boschi, CS Bremec, MB Cousseau, DE Figueroa, DH Rodríguez, N Scarlato, MD Viñas, MN Lewis, PE Penchaszadeh, FH Acuña, ML Aguirre, R Akselman, VA Alder, A Baldoni, MS Barría, RO Bastida, AS Boraso, J Calvo, C Campagna, G Cañete, MC Cassia, PM Cervellini, GE Chiaramonte, M Costagliola, G Cosulich, MC Daponte, JM Díaz de Astarloa, R Elías, GB Esnal, AC Excoffon, H Freije, S García de la Rosa, GN Genzano, DA Giberto, R Guerrero, W Helbling, MS Hoffmeyer, IS Incorvaia, O Iribarne, AJ Jaureguizar, M Kogan, GA Lovrich, AO Madirolas, JP Martin, P Martos, ML Mendoza, S MenuMarque, HW Mianzán, ER Morriconi, RM Negri, S Obenat, CT Pastor de Ward, LB Pérez de Fankhauser, F Quintana, R Reta, R Rico, AM Roux, ME Sabatini, MA Scelzo, L Schejter, ACM Schiavini, RI Silva, MG Silvoni, E Spivak, MI Trucco, EA Vallarino \& DG Zelaya. 2003. Perspectivas de los estudios sobre biodiversidad marina en la Argentina. Gayana 67(2): 371-382.

Perry RI, HP Batchelder, DL Mackas, S Chiba, E Durbin, W Greve \& HM Verheye. 2004. Identifying global synchronies in marine zooplankton populations: issues and opportunities. ICES Journal of Marine Science 61: 445-456.

Reid PC, JM Colebrook, JBL Matthews, J Aiken \& the Continuous Plankton Recorder Team. 2003. The Continuous Plankton Recorder: concepts and history, from Plankton Indicator to undulating recorders. Progress in Oceanography 58: 117-173.

Remsen A, TL Hopkins \& S Samson. 2004. What you see is not what you catch: a comparison of concurrently collected plankton net, Optical Plankton Counter, and Shadowed Image Particle. Profiling Evaluation Recorder data from the northeast Gulf of Mexico. Deep-Sea Research Part I 51: 129-151.

Sieracki CK, ME Sieracki \& CS Yentsch. 1998. An imaginginflow system for automated analysis of marine microplankton. Marine Ecology Progress Series 168: 285296.

Stoecker D. 1998. Conceptual models of mixotrophy in planktonic protists and some ecological and evolutionary implications. European Journal of Protistology 34: 281290.

Tarazona J, D Gutierrez, C Paredes \& A Indacochea. 2003. Una revisión y desafíos para la investigación en biodiversidad marina en Perú. Gayana 67: 206-231.

Warner AJ \& GC Hays. 1994. Sampling by the Continuous Plankton Recorder Survey. Progress in Oceanography 34: 237-256.

Wiebe PH \& MC Benfield. 2003. From the Hensen net towards 4-D biological oceanography. Progress in Oceanography 56: 7-136. 